\title{
Carbon stock and organic fractions in soil under monoculture and Sorghum bicolor-Urochloa ruziziensis intercropping systems
}

\author{
Ranier Vieira Ferreira ${ }^{1}$ (D), Rose Luiza Moraes Tavares ${ }^{1, *}$ (D), Sandrielle Furquim de Medeiros ${ }^{1}$ (D), \\ Alessandro Guerra da Silva ${ }^{1}$ (D), João Fernandes da Silva Júnior ${ }^{2}$ \\ 1. Universidade de Rio Verde - Faculdade de Agronomia - Rio Verde (GO), Brazil. \\ 2. Universidade Federal Rural da Amazônia - Instituto de Ciências Agrárias - Capanema (PA), Brazil.
}

\begin{abstract}
The use of no-till conservationist agricultural systems as well as intercropping in the Cerrado biome are practices that increase soil organic matter (SOM) due to the deposition of straw. This study aimed to quantify the carbon stock and organic fractions of a latosol under off-season monoculture (Sorghum bicolor and Urochloa ruziziensis) and intercropping (S. bicolor-U. ruziziensis) systems, in Rio Verde, state of Goiás, Brazil. Soil samples were collected from different layers: 0-10, $10-20$ and $20-40 \mathrm{~cm}$. The following variables were determined: organic carbon content, carbon stock, dry matter and fractions of organic matter (labile and mineral). The results showed that the organic fractions of the soil are modified according to the adopted management. Intercropping of S. bicolor and U. ruziziensis increased the carbon stock, with the presence of more labile organic fractions on the soil surface, while the use of $U$. ruziziensis enhances the production of recalcitrant organic fractions, promoting greater preservation of the soil organic matter.
\end{abstract}

Key words: cerrado, latosols, organic matter.
Received:

Jan. 31, 2020

Accepted:

May 24, 2020

Section Editor:

Osvaldo Guedes Filho

${ }^{*}$ Corresponding author: roseluiza@unirv.edu.br

\section{INTRODUCTION}

Soils present stabilized organic carbon contents in natural ecosystems, which reflects the environmental conditions determined by climate, vegetation, topography, and the soil characteristics. However, this state might be changed when the soil is used for agricultural purposes (Braida and Reichert 2014). When the soil system loses carbon due to the reduction of soil organic matter (SOM) contents, it generates a decrease in its quality (Lal 2015), interfering in its aggregation (Souza et al. 2016; Fonte et al. 2014), porosity, bulk density (Rossetti and Centurion 2015) and microbial diversity (Moreira et al. 2016) and, consequently, in the carbon stock.

Soil use and management are responsible for the balance of carbon into the soil-atmosphere system. In agricultural systems, carbon entry is influenced by soil preparation, type of crop, crop rotations and fertilization and management of crop residues (Coser et al. 2016; Campos et al. 2011). Additionally, the accumulation of carbon in the soil is strongly related to factors such as climate and soil types (Assad et al. 2013).

Therefore, both the choice of culture and the adopted management system are of great importance, especially in the Cerrado biome, in which soils present low natural fertility. Sorghum bicolor is an alternative in succession to soybean cultivation in off-season in the state of Goiás, Brazil (Silva et al. 2015; 2017). However, intercropping of S. bicolor and other species has not yet being implemented, since intercropping with perennial forage grasses is far more common (Horvathy Neto et al. 2014; Silva et al. 2014; Ribeiro et al. 2015).

Although studies have been focusing on this intercropping system, there is still a lack of reliable data. Sorghum bicolor is already being used for grain production in the off-season, in which there is greater shortage of rain, being considered a 
culture that allows a good adaptation for succession (Ribeiro et al. 2015). In addition, S. bicolor requires less investment when compared with corn (Landau and Martins Netto 2015), which is the predominant crop in the off-season in the region.

According to Silva et al. (2017), graniferous S. bicolor is one of the most important crops sown for the succession of soybeans in the production of off-season grains and forages, especially when intercropped with forage species. Nevertheless, there is a need for more information in order to explore the productive potential of both species.

Intercropping with forages, such as Urochloa ruziziensis, allows the increase of biomass production (Horvathy Neto et al. 2014; Silva et al. 2015), in addition to the large root supply, which contributes to water infiltration and the increase in the levels of organic matter in the superficial layers of the soil (Loss et al. 2013).

The study of fractions of organic matter can be used to assess the dynamics of SOM (Rosset et al. 2016), providing information on changes in soil quality in newly installed management systems. Labile fractions are generally due to freshly decomposed organic matter, while recalcitrant fractions are derived from a more stabilized carbon management system, especially from humic substances responsible for the stabilization of soil aggregates and subsequent physical protection of carbon in the soil (Cambardella and Elliott 1992).

Rossi et al. (2012) detected a C stock in the soil up to $40 \mathrm{Mg} \cdot \mathrm{ha}^{-1}$ and $30 \mathrm{Mg} \cdot \mathrm{ha}^{-1}$ in an area cultivated with $\mathrm{U}$. ruziziensis and S. bicolor, respectively, in the 20-40 cm layer. By evaluating the labile fraction of SOM in the same areas, the authors detected a positive effect of the introduction of Brachiaria spp. due to the greater annual addition and maintenance of plant residues on the soil surface when compared with the management of S. bicolor, since the light fraction is directly related to the material vegetable recently added to the soil.

When U. ruziziensis is intercropped with grains, soil gains tend to increase. Loss et al. (2013) detected a higher C stock (10-13 Mg.ha $\mathrm{M}^{-1}$ ) when compared with corn monoculture (9-11 Mg.ha-1) in a 0-10 cm layer. In addition, according to the authors the systems of integration with $U$. ruziziensis provide a more balanced distribution of the labile and mineral fractions in soil layers when compared with monoculture systems.

This study aimed to quantify the carbon stock and organic fractions of a latosol under off-season monoculture (S. bicolor and U. ruziziensis) and intercropping (S. bicolor-U. ruziziensis) systems, in Rio Verde, state of Goiás, Brazil.

\section{MATERIAL AND METHODS}

\section{Experimental area}

The experiment was conducted under field conditions of Cerrado Biome (coordinates $17^{\circ} 46^{\prime} 58.65^{\prime \prime} \mathrm{S}$, longitude $50^{\circ} 58^{\prime} 13.08^{\prime \prime}$ W, altitude $783 \mathrm{~m}$ ). According to the Koppen classification (Köppen and Geiger 1928), the climate of the region is classified as Aw, with two well-defined seasons (dry winters and wet summers) (Fig. 1). The soil of the area is classified as a dystrophic red latosol, with a clayey texture (Table 1).

The experiment started with the collection of soybean productivity data from the 2016/2017 harvest. The area has a history of soybean cultivation from the cultivar NA $7337 \mathrm{RR}$, with a population of 340,000 seeds $^{\circ} \cdot \mathrm{ha}^{-1}$ in the harvest period and corn in the off-season for a period of 6 years.

\section{Treatments}

The treatments consisted of areas with different histories of off-season agricultural cultivation: S. bicolor monoculture, $U$. ruziziensis monoculture and S. bicolor-U. ruziziensis intercropping. The experiment was organized in a randomized block design with four replications. The plots consisted of eight $9 \mathrm{~m}$ long lines, spaced at $45 \mathrm{~cm}$ from each other.

In the off-season (March 2017), the monoculture and agricultural intercropping systems of S. bicolor and U. ruziziensis were installed, ending in August 2017, with S. bicolor harvest and U. ruziziensis desiccation. In October 2017, soybean 'NA 7337 RR' was planted for the 2017/2018 harvest, which was harvested in January 2018. 


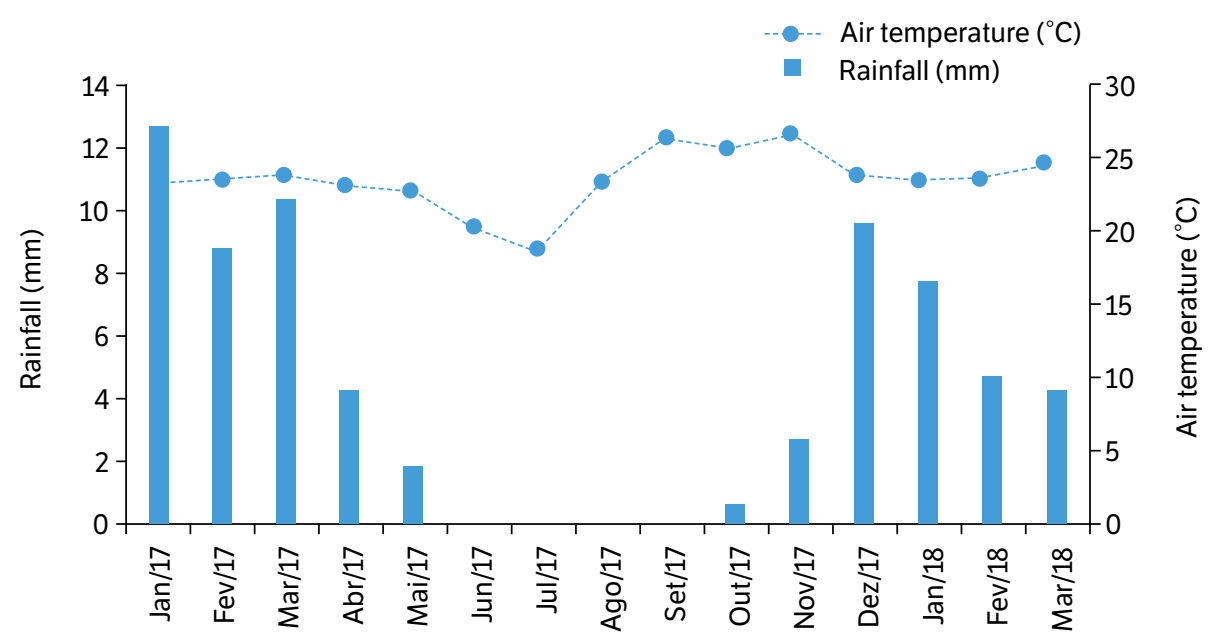

Figure 1. Monthly variation of average air temperature and rainfall from March 2017 to March 2018, in Rio Verde, state of Goiás, Brazil.

Table 1. Chemical characterization of the soil with off-season cultivation of Sorghum bicolor and Urochloa ruziziensis managed under monoculture and intercropping systems.

\begin{tabular}{|c|c|c|c|c|c|c|c|c|c|c|}
\hline Depth & $\mathbf{P}$ & $\mathbf{S}$ & K & $\mathrm{Ca}$ & $\mathbf{M g}$ & Al & CEC & $\mathrm{pH}$ & $\mathbf{v}$ & OM \\
\hline$(\mathrm{cm})$ & \multicolumn{3}{|c|}{----- mg·dm $\mathbf{d m}^{-3}$----- } & \multicolumn{3}{|c|}{--- $\mathrm{cmol}_{\mathrm{c}} \cdot \mathrm{dm}^{-3}$--- } & - & - & \multicolumn{2}{|c|}{----- \% ----- } \\
\hline $0-20$ & 21.3 & 13.8 & 47.7 & 2.2 & 1.0 & 0.0 & 5.2 & 1.3 & 7.3 & 4.5 \\
\hline $20-40$ & 13.0 & 9.3 & 36.0 & 1.2 & 0.6 & 0.2 & 4.7 & - & 5.8 & 3.21 \\
\hline
\end{tabular}

* Chemical analysis before the installation of the experiments (January, 2017).

The hybrid Taguá was used to cultivate S. bicolor in the off-season using both monoculture and intercropping with U. ruziziensis. A total of 170,000 seeds $\cdot h^{-1}$ was used. Urochloa ruziziensis cultivation was carried out together with the basic top-dressing fertilization at a bulk density of $13 \mathrm{~kg} \cdot \mathrm{ha}^{-1}$, VC $46 \%$. For the basic fertilization, the equivalent to $170 \mathrm{~kg} \cdot \mathrm{ha}^{-1}$ of $\mathrm{P}_{2} \mathrm{O}_{5}$ and 200 and $150 \mathrm{~kg} \cdot \mathrm{ha} \mathrm{a}^{-1}$ of $\mathrm{N}$ were used.

\section{Soil sampling}

Undisturbed soil samples were collected for analysis of soil bulk density and deformed samples for analysis of organic carbon contents, texture and physical fractionation of organic matter. Samples were collected between the crop lines.

In each plot, a trench with dimensions of $0.4 \mathrm{~m}$ wide $\times 0.8 \mathrm{~m}$ long $\times 1.30 \mathrm{~m}$ high was opened and unformed soil samples were taken in triplicate with the aid of $100 \mathrm{~cm}^{3}$ volumetric rings in the depths $0-10,10-20$ and $20-40 \mathrm{~cm}$.

The deformed samples were collected with the aid of a Dutch auger at four different points in each plot at the same depths mentioned above. The four simple samples were homogenized for composite sample composition, which were stored in plastic bags.

\section{Soil analysis}

Soil assessments were performed after the crop cycle, in February 2018, after soybean harvest.

The determination of the organic carbon contents of the soil was carried out according to the methodology proposed by Sims and Haby (1971), based on the oxidation of the organic matter of the soil with potassium dichromate in a strongly acid medium. The determination was performed in a spectrophotometer at $600 \mathrm{~nm}$. The data were calculated using a standard curve prepared with sucrose solution. The analysis of soil bulk density was carried out according to the methodology proposed by Embrapa (1997), based on the collection of soil samples with undeformed structure through a steel ring (Kopecky) with 
sharp edges and an internal volume of $100 \mathrm{~cm}^{3}$. It is a simple analysis procedure that consists of obtaining the dry mass value of the soil after being subjected to a temperature of $105^{\circ} \mathrm{C}$ for $24 \mathrm{~h}$.

The $C$ stock values were corrected based on the equivalent mass of soil, according to Lee et al. (2009), in order to equalize the differences in soil density of the management systems using carbon and soil density data from a reference area (native forest).

The method of physical fractionation of the SOM was carried out according to the methodology proposed by Cambardella and Elliott (1992), in which the following fractions were obtained: carbon bonded to the mineral fraction of the soil (C-MIN) and carbon of the labile fraction (C-LF). A total of $20 \mathrm{~g}$ of soil and $60 \mathrm{~mL}$ of sodium hexametaphosphate solution (5 g.L-1 $)$ were homogenized for $16 \mathrm{~h}$ on a horizontal shaker. After homogenization, the suspension was poured through a $53 \mu \mathrm{m}$ sieve. The material retained in the sieve consisted of the labile fraction associated with sandy forms, and the sieved material corresponded to the mineral fraction associated with silt and clay. The material retained in the sieve, after washing, was transferred to petri dishes and dried in a forced air circulation oven at $50^{\circ} \mathrm{C}$ until constant weight. Subsequently, the carbon content of the samples was determined as previously described.

\section{Dry matter analysis}

The analysis of the content of dry matter was carried out at the end of the off-season crop cycle (September 2017) using green mass delimited by a $1 \mathrm{~m}^{2}$ wooden square, which was thrown randomly in each plot in triplicates. The canopy of plants was cut at the base, leaving the vegetation $20 \mathrm{~cm}$ high. The green mass was dried at $60{ }^{\circ} \mathrm{C}$ in a forced air oven for $72 \mathrm{~h}$, and the weight was extrapolated to $\mathrm{Mg} \cdot \mathrm{ha}^{-1}$.

\section{Statistical analysis}

The experimental design was carried out in randomized blocks (DBC) with four blocks. The statistical model for data interpretation was divided into plots, with cultivation systems (S. bicolor, U. ruziziensis and S. bicolor-U. ruziziensis intercropping) as the first factor and soil depths as the second factor (0-10, 10-20 and 20-40 cm), totaling 36 experimental units. Analysis of variance (ANOVA) was performed and the Tukey's test was applied at 5\% probability level for comparison of means, using Sisvar statistical software (Ferreira 2003).

\section{RESULTS AND DISCUSSION}

The production of dry matter in the area with U. ruziziensis monoculture was higher $(\mathrm{p}<0.05)$ than the area with S. bicolor-U. ruziziensis intercropping and S. bicolor monoculture, with values of $14.72,10.48$ and $6.37 \mathrm{Mg} \cdot \mathrm{ha}^{-1}$, respectively (Fig. 2). These values were higher than those found by Rossi et al. (2012), in a dystrophic red latosol in Montividiu, state of Goiás, Brazil, with values of 6.10 and $3.85 \mathrm{M} \cdot \mathrm{ha}^{-1}$, respectively, for areas planted with U. ruziziensis and S. bicolor under monoculture systems. However, they are similar to the values found by Kliemann et al. (2006) of 12 and $6 \mathrm{Mg} \cdot \mathrm{ha}^{-1}$ for areas under cultivation of U. ruziziensis and S. bicolor, respectively, in Santo Antônio da Barra, state of Goiás. Pittelkow et al. (2012) detected biomass values of 10 and $6 \mathrm{Mg} \cdot \mathrm{ha}^{-1}$ for an area with U. ruziziensis and S. bicolor, respectively, in Sorriso, state of Mato Grosso.

U. ruziziensis straw presents a higher $\mathrm{C} / \mathrm{N}$ ratio when compared with S. bicolor. Silva et al. (2017) found values of $\mathrm{C} / \mathrm{N}$ ratio in a S. bicolor-U. ruziziensis intercropping system ranging from 68 to 72 , while the ratio was 62 for monoculture $S$. bicolor. This indicates that higher $\mathrm{C} / \mathrm{N}$ ratios of $U$. ruziziensis slow down the decomposition of organic matter, allowing longer time in the soil, gradually releasing carbon and nutrients in the soil.

The carbon stock values ranged from 2.0 to $3.3 \mathrm{~kg} \cdot \mathrm{m}^{-2}\left(20\right.$ to $\left.33 \mathrm{Mg} \cdot \mathrm{ha}^{-1}\right)$ and are similar to the values found in studies of carbon stocks in Cerrado soils (Rossi et al. 2012; Loss et al. 2013; Rossetti and Centurion 2015).

The carbon stock was higher $(\mathrm{p}<0.05)$ in the system with S. bicolor-U. ruziziensis intercropping when compared with the S. bicolor and U. ruziziensis monoculture systems, with values of $3.36,2.79$ and $2.74 \mathrm{Mg} \cdot \mathrm{kg}^{-1}$, respectively, in the $0-10 \mathrm{~cm}$ 
soil layer (Table 2). The same trend was observed for the carbon content in the soil, with values of $25,21.8$ and $21.1 \mathrm{~g} \cdot \mathrm{kg}^{-1}$, respectively (Table 2).

This effect can be attributed to the intercropping system, which provided a greater deposit of organic matter on the soil surface resulting from the greater diversity of coverings. Campos et al. (2011) and Rossetti and Centurion (2015), when evaluating agricultural intercropping systems between S. bicolor and U. ruziziensis, found similar results. The authors verified an increase in carbon, mainly in the topsoil, with a tendency to decrease within soil depth.

According to Rossi et al. (2012), the carbon content in the soil decreases within soil depth in a no-tillage system due to the residues that are deposited on the surface, not being incorporated as in the conventional system. Thus, this action implies better carbon stability (Rosset et al. 2016).

The highest carbon stock in intercropping systems is enhanced when there is inclusion of $U$. ruziziensis. According to Ribeiro et al. (2015), U. ruziziensis, which presents good adaptability, promotes a large amount of vegetable input on the soil and in the Cerrado biome.

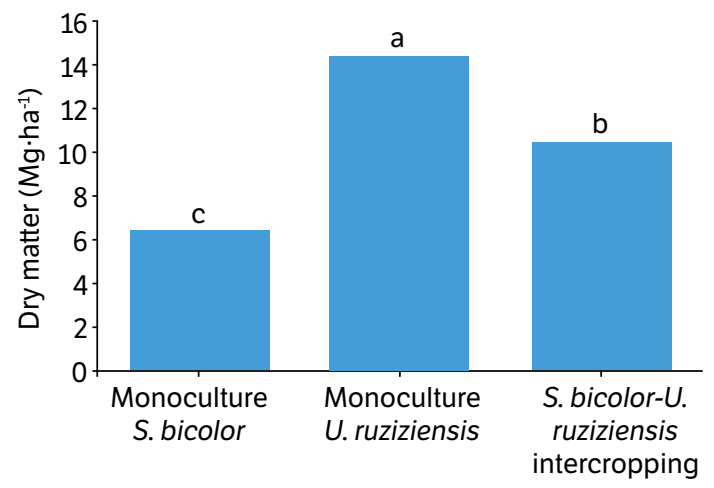

Figure 2. Dry matter production in an area under monoculture systems and agricultural intercropping of Sorghum bicolor and Urochloa ruziziensis in Rio Verde, state of Goiás, Brazil. Averages followed by the same letter do not differ significantly from each other by the Tukey's test at $5 \%$ probability level.

Table 2. Average values of carbon stock (EstC), organic carbon (Corg), light fraction carbon (C-FL) and mineral fraction carbon (C-FM) in the off-season, in Rio Verde-GO.

\begin{tabular}{|c|c|c|c|c|}
\hline \multirow{2}{*}{ Cultivation system } & EstC & Corg & C-FL & C-FM \\
\hline & $\mathrm{Kg} \cdot \mathrm{m}^{-2}$ & \multicolumn{3}{|c|}{---- g·kg $\mathbf{~}^{-1}$---- } \\
\hline & \multicolumn{4}{|c|}{$0-10 \mathrm{~cm}$} \\
\hline Monoculture S. bicolor & $2.74 \mathrm{bA}$ & $21.14 \mathrm{bA}$ & $2.34 \mathrm{bA}$ & $10.87 \mathrm{bA}$ \\
\hline Monoculture U. ruziziensis & $2.79 \mathrm{bA}$ & $21.80 \mathrm{bA}$ & $7.26 \mathrm{aA}$ & $18.03 \mathrm{aA}$ \\
\hline \multirow[t]{2}{*}{ S. bicolor-U. ruziziensis intercropping } & $3.36 \mathrm{aA}$ & $25.26 \mathrm{aA}$ & $10.04 \mathrm{aA}$ & $10.03 \mathrm{cA}$ \\
\hline & \multicolumn{4}{|c|}{$10-20 \mathrm{~cm}$} \\
\hline Monoculture S. bicolor & $2.71 \mathrm{aA}$ & $17.62 \mathrm{aB}$ & $0.88 \mathrm{bA}$ & $10.67 \mathrm{bA}$ \\
\hline Monoculture U. ruziziensis & $2.67 \mathrm{aA}$ & $17.29 \mathrm{aB}$ & $6.22 \mathrm{aA}$ & $15.14 \mathrm{aAB}$ \\
\hline \multirow[t]{2}{*}{ S. bicolor-U. ruziziensis intercropping } & $2.66 \mathrm{aB}$ & $17.73 \mathrm{aB}$ & $5.99 \mathrm{aB}$ & $9.17 \mathrm{cAB}$ \\
\hline & \multicolumn{4}{|c|}{$20-40 \mathrm{~cm}$} \\
\hline Monoculture S. bicolor & $2.16 \mathrm{aB}$ & $13.88 \mathrm{bC}$ & $2.23 \mathrm{bA}$ & $10.04 \mathrm{bA}$ \\
\hline Monoculture U. ruziziensis & $2.40 \mathrm{aB}$ & $16.64 \mathrm{aB}$ & $6.05 \mathrm{aA}$ & $12.46 \mathrm{aB}$ \\
\hline S. bicolor-U. ruziziensis intercropping & $2.31 \mathrm{aC}$ & $15.57 \mathrm{abB}$ & $4.11 \mathrm{aB}$ & $5.94 \mathrm{cB}$ \\
\hline
\end{tabular}

Averages followed by the same letter in the column do not significantly differ from each other by the Tukey's test at $5 \%$ probability level. Lowercase letters compare the effect the management systems in each soil depth and uppercase letters compare the effect of soil depth in each management. 
In this context, intercropping of U. ruziziensis and S. bicolor represents a second crop alternative, in succession to soybeans, to maintain soil quality.

The soil with the presence of $U$. ruziziensis cultivated in isolation or in intercropping presented higher carbon contents in the labile fraction (C-FL) when compared with monoculture S. bicolor in all soil depths (Table 2), in which differences represented 3 and $4 \times$ more C-FL in the 0-10 cm layer, 7 and $6 \times$ in the $10-20 \mathrm{~cm}$ layer and 2 and $1 \times$ in the 20-40 cm layer, respectively for soil with $U$. ruziziensis in monoculture or intercropped when compared with monoculture of S. bicolor. This effect can be attributed to the greater supply of dry material by U. ruziziensis (Table 2). This can be attributed to the greater amount of $U$. ruziziensis straw, since the labile fraction is directly related to the plant material recently added to the soil (Rossi et al. 2012; Bayer et al. 2004).

Similarly, Loss et al. (2013) observed a higher content of labile fraction of SOM in a no-till area in the Cerrado, with the use of a greater number of crops in the management system (sunflower/millet/soybean and corn).

Another hypothesis is that the rapid development of $U$. ruziziensis roots promotes concentration of the labile fraction, since this fraction is directly related to the plant material recently added to the soil or recently decomposed.

Rossi et al. (2012) found greater accumulation of C-LF in soil with U. ruziziensis cultivation when compared with S. bicolor, with values ranging from $15-10 \mathrm{~g} \cdot \mathrm{kg}^{-1}$ and from $11-05 \mathrm{~g} \cdot \mathrm{kg}^{-1}$, respectively. Those results are similar to the results found in the present study, with 10-4, 7-6 and 2-08 g.kg-1 for S. bicolor-U. ruziziensis intercropping, monoculture U. ruziziensis and monoculture $S$. bicolor, respectively.

This variation might be an indication that this compartment can be used as an indicator of soil quality, mainly in the evaluation of recent management systems, where the total organic carbon (TOC) contents of the soil are not of great magnitude.

The amount of carbon in the mineral fraction (C-FM) was higher in the soil under monoculture U. ruziziensis (up to $12 \mathrm{~g} \cdot \mathrm{kg}^{-1}$ ), followed by monoculture S. bicolor (up to $10 \mathrm{~g} \cdot \mathrm{kg}^{-1}$ ) and S. bicolor-U. ruziziensis intercropping (up to $5 \mathrm{~g} \cdot \mathrm{kg}^{-1}$ ), respectively (Table 2).

The SOM associated with minerals presents a considerably slower cycle in terms of formation and decomposition. This suggests the potential of $U$. ruziziensis in promoting increased carbon in the soil, whether in the release of heavy (C-FM) or labile (C-FL) fractions. According to Loss et al. (2013), the use of U. ruziziensis tends to provide a more balanced distribution of very labile and recalcitrant carbon throughout the soil layers.

Rosset et al. (2016) concluded that the cultivation of crops in succession contributes to the increase of the more labile fractions, but not to the increase of the more recalcitrant fractions of carbon. In addition, the same authors identified a predominance of labile fractions of surface organic matter. This effect was also verified in the present study, with the labile and mineral fractions presenting antagonistic behaviors within soil depths.

Despite the benefits presented to the soil, the off-season management systems did not show significant gains to the following crop. The results of soybean productivity did not show significant difference $(\mathrm{p}<0.05)$ with different histories of off-season cultivation systems (Fig. 3). Soybean remained in the field until the harvest with a short time of adoption

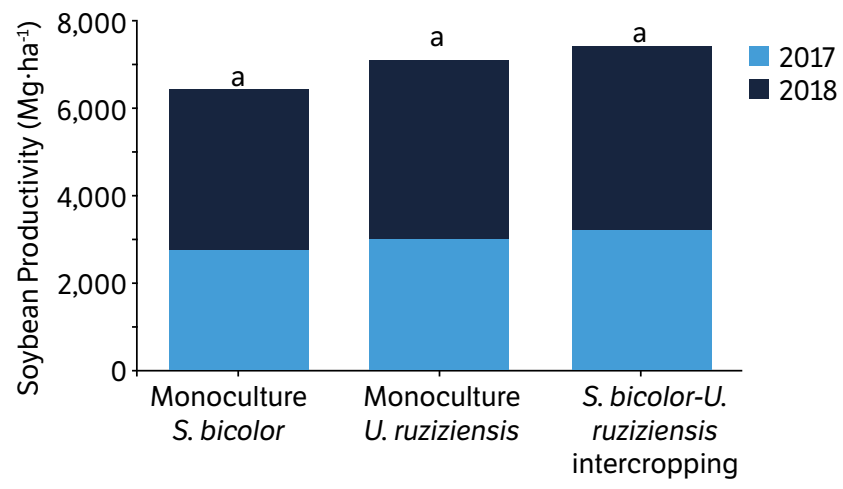

Figure 3. Soybean productivity in the harvest before (February 2018) and after (January 2019) the installation of the second cycle of the monoculture and intercropping systems using the Sorghum bicolor and Urochloa ruziziensis, in Rio Verde, state of Goiás, Brazil. Means followed by the same letter do not differ significantly by the Tukey's test at $5 \%$ probability level. 
of the systems in the off-season. In addition, it was possible to observe that there was no chemical limitation of the soil regarding production (Table 1).

Melotto et al. (2017) pointed out that soybean productivity was systematically higher in the intercropping system in the off-season, suggesting a possible improvement in soil conditions, especially when U. ruziziensis is included.

\section{CONCLUSION}

The organic fractions of the soil were highly modified according to the adopted soil management. The use of S. bicolor-U. ruziziensis intercropping system promoted more labile organic fractions on the soil surface, in addition to a greater carbon stock.

U. ruziziensis provided higher levels of dry matter in monoculture, in addition to enhancing the production of recalcitrant organic fractions, promoting greater soil conservation.

Higher carbon stock and fractions of soil organic matter were found in the topsoil.

\section{ACKNOWLEDGMENTS}

The authors thank the Universidade de Rio Verde for their support to the research activities and the company De Lollo Agronegócios (Rio Verde/GO) for ceding the experimental area.

\section{FUNDING}

This work was supported by the Graduate Program in Plant Production from Universidade de Rio Verde and was financed in part by the Coordenação de Aperfeiçoamento de Pessoal de Nível Superior - Brasil (CAPES) - Finance Code 001 [http://doi.org/10.13039/501100002322]

\section{AUTHOR'S CONTRIBUTION}

Conceptualization, Tavares R. L. M.; Methodology, Ferreira R. V., Medeiros S. F. and Tavares R. L. M.; Investigation, Ferreira R. V. and Medeiros S. F.; Writing - Original Draft, Ferreira R. V., Medeiros S. F. and Tavares R. L. M.; Writing Review and Editing, Tavares R. L. M., Silva A. G. and Silva Júnior J. F.; Funding Acquisition: Tavares R. L. M. and Silva A. G.; Supervision, Tavares R. L. M.

\section{REFERENCES}

Assad, E. D., Pinto, H. S., Martins, S. C., Groppo, J. D., Salgado, P. R., Evagelista, B., Vasconcelos, E., Sano, E. E., Pavão, E., Lunar, R., Camargo, P. B. and Martinelli, L. A. (2013). Changes in soil carbon stocks in Brazil due to land use: paired site comparisons and a regional pasture soil survey. Biogeosciences, 10, 6141-6160. https://doi.org/10.5194/bg-10-6141-2013

Bayer, C., Martin-Neto, L., Mielniczuk, J. and Pavinato, A. (2004). Armazenamento de carbono em frações lábeis da matéria orgânica de um Latossolo Vermelho sob plantio direto. Pesquisa Agropecuária Brasileira, 39, 677-683. https://doi.org/10.1590/S0100-204X2004000700009 Braida, J. A. and Reichert, J. M. (2014). Matéria orgânica e comportamento mecânico para fins de manejo de solo. In L. F. C. Leite, G. A. Maciel and A. S. F. Araújo (Eds.), Agricultura Conservacionista no Brasil (p. 309-361). Brasília: Embrapa. 
Cambardella, C. A. and Elliott, E. T. (1992). Particulate soil organic matter changes across a grassland cultivation sequence. Soil Science Society of America Journal, 56, 777-783. https://doi.org/10.2136/sssaj1992.03615995005600030017x

Campos, B.-H. C., Amado, T. J. C., Bayer, C., Nicoloso, R. S. and Fiorin, J. E. (2011). Carbon stock and its compartments in a subtropical oxisol under long-term tillage and crop rotation systems. Revista Brasileira de Ciência do Solo, 35, 805-817. https://doi.org/10.1590/ S0100-06832011000300016

Coser, T. R., Ramos, M. L. G., Figueiredo, C. C., Carvalho, A. M., Cavalcante, E., Moreira, M. K. R., Araujo, P. S. M. and Oliveira, S. A. (2016). Soil microbiological properties and available nitrogen for corn in monoculture and intercropped with forage. Pesquisa Agropecuária Brasileira, 51, 1660-1667. https://doi.org/10.1590/s0100-204×2016000900066

[EMBRAPA] Empresa Brasileira de Pesquisa Agropecuária. (1997). Manual de Métodos de Análise de Solo. Centro Nacional de Pesquisa de Solos. Rio de Janeiro: Embrapa. [Accessed Jun. 10 2020]. Available at: https://www.agencia.cnptia.embrapa.br/Repositorio/ Manual+de+Metodos_000fzvhotqk02wx5ok0q43a0ram31wtr.pdf

Ferreira, D. F. (2003). Software Sisvar Versão 4.2. Lavras: UFLA. [Accessed Jul. 9, 2020]. Available at: http://www.biometria.ufla.br/index. php/BBJ/article/view/450.

Fonte, S. J., Nesper, M., Hegglin, D., Velásquez, J. E., Ramirez, B., Rao, I. M., Bernasconi, S. M., Bünemann, E. K., Frossard, E. and Oberson, A. (2014). Pasture degradation impacts soil phosphorus storage via changes to aggregate-associated soil organic matter in highly weathered tropical soils. Soil Biology and Biochemistry, 68, 150-157. https://doi.org/10.1016/j.soilbio.2013.09.025

Horvathy Neto, A., Silva, A. G., Teixeira, I. R., Costa, K. A. P. and Assis, R. L. (2014). Consórcio de sorgo granífero e braquiária na safrinha para produção de grãos e forragem. Revista Caatinga, 27, 132-141.

Kliemann, H. J., Braz, A. J. P. B. and Silveira, P. M. (2006). Taxas de decomposição de resíduos de espécies de cobertura em latossolo vermelho distroférrico. Pesquisa Agropecuária Tropical, 36, 21-28.

Köppen, W. and Geiger, R. (1928). Klimate der Erde. Gotha: Verlag Justus Perthes. Wall-map $150 \mathrm{~cm} 200 \mathrm{~cm}$.

Lal, R. (2015). Restoring soil quality to mitigate soil degradation. Sustainability, 7, 5875-5895. https://doi.org/10.3390/su7055875

Landau, E. C. and Martins Netto, D. A. (2015). Expansão potencial da produção de sorgo granífero no Brasil no sistema de rotação com soja considerando o zoneamento de risco climático 2015/16 [Boletim de Pesquisa e Desenvolvimento 125]. Sete Lagoas: Embrapa Milho e Sorgo. [Accessed Jul. 9, 2020]. Available at: https://ainfo.cnptia.embrapa.br/digital/bitstream/item/140133/1/bol-125.pdf

Lee, J., Hopmans, J. W., Rolston, D. E., Baer, S. G. and Six, J. (2009). Determining soil carbon stock changes: Simple bulk density corrections fail. Agriculture, Ecosystems \& Environment, 134, 251-256. https://doi.org/10.1016/j.agee.2009.07.006

Loss, A., Pereira, M. G., Perin, A., Beutler, S. J. and Anjos, L. H. C. (2013). Oxidizable carbon and humic substances in rotation systems with brachiaria/livestock and pearl millet/no livestock in the Brazilian Cerrado. Spanish Journal of Agricultural Research, 11, $217-231$. https://doi.org/10.5424/sjar/2013111-3416

Melotto, A. M., Lourenção, A. L. F., Grigolli, J. F. J. and Gitti, D. C. (2017). Implantação do consórcio milho e capins em Mato Grosso do Sul: Principais Aspectos. In A. L. F. Lourenção, J. F. J Grigolli, A. M. Melotto and D. C. Gitti (Eds.), Tecnologia e produção: Milho safrinha 2016. Maracaju: Fundação MS.

Moreira, M. K. D. R., Araujo, P. S., Oliveira, S. A. D. (2016). Soil microbiological properties and available nitrogen for corn in monoculture intercropped with forage. Pesquisa Agropecuária Brasileira, 51, 1660-1667.

Pittelkow, F. K., Scaramuzza, J. F., Weber, O. L. S., Maraschin, L., Valadão, F. C. A. and Oliveira, E. S. (2012). Produção de biomassa e acúmulo de nutrientes em plantas de cobertura sob diferentes sistemas de preparo do solo. Revista Agrarian, 5, $212-222$. 
Ribeiro, M. G., Costa, K. A. P., Silva, A. G., Severiano, E. C., Simon, G. A., Cruvinel, W. S., Silva, V. R. and Silva, J. T. (2015). Grain sorghum intercropping with Brachiaria brizantha cultivars in two sowing systems as a double crop. African Journal of Agricultural Research, 10, 3759-3766.

Rosset, J. S., Lana, M. C., Pereira, M. G., Schiavo, J. A., Rampim, L. and Sarto, M. V. M. (2016). Frações químicas e oxidáveis da matéria orgânica do solo sob diferentes sistemas de manejo, em Latossolo Vermelho. Pesquisa Agropecuária Brasileira, 51, 1529-1538. https:// doi.org/10.1590/s0100-204×2016000900052

Rossetti, K. V. and Centurion, J. F. (2015). Estoque de carbono e atributos físicos de um Latossolo em cronossequência sob diferentes manejos. Revista Brasileira de Engenharia Agrícola e Ambiental, 19, 252-258. https://doi.org/10.1590/1807-1929/agriambi.v19n3p252-258

Rossi, C. Q., Pereira, M. G., Giácomo, S. G., Betta, M. and Polidoro, J. C. (2012). Frações lábeis da matéria orgânica em sistema de cultivo com palha de braquiária e sorgo. Revista Ciência Agronômica, 43, 38-46.

Silva, A. G., Moraes, L. E., Horvathy Neto, A., Teixeira, I. R. and Simon, G. A. (2014). Consórcio sorgo e braquiária na entrelinha para produção de grãos, forragem e palhada na entressafra. Revista Ceres, 61, 697-705. https://doi.org/10.1590/0034-737X201461050013

Silva, A. G., Horvathy Neto, A., Teixeira, I. R., Costa, K. A. P. and Braccini, A. L. (2015). Selection of sorghum and Brachiaria cultivars in intercropping for straw and grains production. Semina: Ciências Agrárias, 36, 2951-2964. https://doi.org/10.5433/1679-0359.2015v36n5p2951

Silva, A. G., Andrade, C. L. L., Goulart, M. M. P., Teixeira, I. R., Simon, G. A. and Moura, I. C. S. (2017). Consórcio de sorgo granífero com braquiárias na safrinha para produção de grãos e biomassa. Revista Brasileira de Milho e Sorgo, 16, 495-508. https://doi.org/10.18512/19806477/rbms.v16n3p495-508

Sims, J. R. and Haby, V. A. (1971). Simplified colorimetric determination of soil organic matter. Soil Science, 112, 137-141. https://doi. org/10.1097/00010694-197108000-00007

Souza, E. D., Carneiro, M. A. C., Paulino, H. B., Ribeiro, D. O., Bayer, C. and Rotta, L. A. (2016). Matéria orgânica e agregação do solo após conversão de "campos de murundus" em sistema plantio direto. Pesquisa Agropecuária Brasileira, 51, 1194-1202. https://doi. org/10.1590/s0100-204×2016000900019 